\title{
Computer Self-Efficacy and Facilitating Conditions as Correlates of Behavioural Intention to Use Electronic Information Resources by Master of Business Administration Students in Federal Universities in Nigeria
}

\author{
Bamidele Olawale $^{1^{*}}$, S. O. Popoola ${ }^{2}$ \\ ${ }^{1}$ University Library \\ Ekiti State University, Nigeria \\ ${ }^{2}$ Department of Library, Archival and Information Studies \\ University of Ibadan, Nigeria \\ *Corresponding author's email: bamex001 [AT] gmail.com
}

\begin{abstract}
The focus of this research work was to investigate computer self-efficacy and facilitating conditions as correlates of behavioural intention to use electronic information resources by MBA students in Nigeria federal universities. Cluster sampling technique was adopted for the study and systematic sampling technique was used to select $60 \%$ of the total population of the MBA students across the ten federal universities offering the programme based on probability and proportionate size. Data were collected using questionnaire designed to elicit response from respondents and analysed using Pearson Product Moment Correlation Analysis, Multiple Regression Analysis using Partial Lease Square Method (PLSEM), Mean, Standard Deviation and Percentages. However, out of one thousand two hundred and seventy $(1,270)$ copies of questionnaire administered to the respondents, one thousand and fifteen copies $(1,015)$ were returned which represents $79.9 \%$ response rate for the study. Findings revealed that the level computer self-efficacy and facilitating conditions of MBA students towards use of electronic information resources in Nigeria federal universities was high. However, the study concluded that university managements and librarians should ensure rapid adoption and diffusion of ICTs and be proactive by developing relevant ICT policies and strategies toward effective and sustainable electronic information resources development in Nigerian universities, as well as promoting the use of relevant electronic information resources by $M B A$ students to improve their quality of research and global competitiveness.
\end{abstract}

Keywords--- Computer self-efficacy, facilitating conditions, behavioural intention, electronic information resources, MBA students, Nigeria universities.

\section{INTRODUCTION}

Electronic information resources (EIRs) are information stored digitally in computer or computer related facilities such as CD-ROMs, flash drives, digital repositories or the Internet. Thus, Haridasan and Khan (2009) defined electronic information resources as resources in which information is stored digitally which are accessible through electronic systems and networks. Shuling (2007) opined that electronic information resources (EIRs) are gradually becoming the major resources in every university library. The emergence of electronic information resources transformed information handling and management in the academic environment and in university libraries.

Electronic information resources have the potential to increase the learning opportunities offered to Master of Business Administration (MBA) students, by providing access to a variety of exercises and making learning more lively and interactive. Electronic information resources promote efficiency in disseminating information for learning and research purposes in the universities, through the use of EIRs, MBA students can have access to global electronic information resources to enhance their academic performance (Thanuskodi, 2012). Furthermore EIRs are more easily updated than the print resources. Electronic information resource is more of a tool to assist in conducting research and offers an advantage of searching for materials quickly. As the role of libraries continues to change, librarians are intensifying efforts to make more electronic information resources available for use of students particularly MBA students (Deng, 2010).

Master of Business Administration (MBA) students are specifically trained to be world class managers capable of turning around the management of their various organisations and invariably contributing positively to the economic growth of the nation. The academic work for the MBA students is no doubt very cumbersome as they have to keep abreast of information pertinent to their course work both on past and current issues in the field of management and economic issues. They are expected to be able to forecast, analyse and speculate possible outcomes over a range of policy issues, 
strategic planning and decision making within their industry, country and international boundaries. Thus, they require much information and mix of resources to enhance their intellectual capacity to cope with the challenges they face in the course of their studentship. EIRs are therefore a very crucial tool for MBA students, and how they acquire and use the information are key determinants of their academic performance. (Emmanuel and Jegede, 2011).

To cope effectively with the challenges of the MBA programme, students should use electronically stored information in computers and other related computer facilities for better academic performance (Dilek-Kayaoglu, 2008). In view of the potential advantages of EIRs (such as ease of access and currency of information) over print resources in modern electronic information environment, use of electronic information resources is fast becoming a norm in research in the universities around the world and MBA students should not be left behind. Different types of EIRs include: ejournals, e-books, online databases, e-theses/e-dissertations, electronic conference proceedings, electronic technical reports, electronic reference documents, CD-ROM databases and Internet resources (Swain, 2010). Appleton (2006) classified Internet resources into freely available web-based resources and scholarly web-based resources such as electronic journals. The scholarly web-based resources such as electronic journals, electronic books and online databases are invaluable EIRs that brought great innovations in research process in universities.

Tan, Sim, Ooi and Phusavat (2012) argued that the most important factor that determines MBA students' acceptance and use of EIRs is their behavioural intention. Intentions are defined as plans or goals. People sometimes fall short of achieving their goals, which raises the question of whether respondents take this into account when stating their intentions. Therefore, behavioural intention to use EIRs reflects how hard a person is willing to try and how motivated he or she is to use EIRs. In theory, it serves as the most proximate predictor of behaviour (Ajzen, 1991). In this case, it describes MBA students' perceived likelihood to make use of EIRs.

Behavioural intention has been used as dependent variable in many studies perhaps because of its robust ability to predict behaviour which is the central goal of behavioural intention models (Ibrahim and Najjar, 2008). Behavioural intention of students' use of EIRs can be either favourable or unfavourable. Favourable behavioural intention often results into bonding with the e-library services provided, increased frequency of use, and a willingness to pay for the cost of access. On the contrary, unfavourable behavioural intention lead users to display higher probability of low use, engage in negative word of mouth to discourage other users, and display unwillingness to pay for access cost (Ladhari, 2009).

Computer self-efficacy theory is a construct of perceived behavioural control which is a variable in this study. It is derived from Bandura's self-efficacy which in turn is based on Social Cognitive Theory. Bandura (1977) defined selfefficacy as an individual's confidence in his ability to perform the task required to produce specific outcome. In another vein, Bandura (1986) advanced the concept of self-efficacy as people's judgement of their capabilities to organise and execute causes of action required to attain designated types of performance.

It is assumed that MBA students with a strong sense of computer self-efficacy will be able to adapt and be competent in the use of EIRs and will be able to adapt in their learning and research activities in the university system. But those who are beset with low computer self-efficacy will suffer physical and emotional strain (Bandura, 1996). It was concluded that the stronger the computer self- efficacy, the more likely will the person pursue challenging computing tasks, persist on them and perform them successfully and competently. An individual might have high computer self-efficacy in using the Internet but low computer self-efficacy when asked to design a database.

Computer self-efficacy is seen by some as being a better predictor of behavioural intention to use EIRs than actual use. Sam, Othman, and Nording, (2011) in their study on computer self-efficacy, computer anxiety and attitude towards the internet among undergraduates in UNIMAS, Malaysia, observed that frequency of use is a factor that has a bearing on computer self-efficacy. An individual's computer self- efficacy toward an application can decline during periods of inactivity with that particular application. Similarly, frequency of use is likely to increase computer self-efficacy because the more you use a computer system the better you are. Sam et.al (2011) observed that, since computer self-efficacy refers to a person's perception of his computing ability, fundamentally, this suggests that a person's perception of his ability in certain tasks can very much depend on whom they are comparing themselves with and the past experiences with computer tasks.

Smith (2011), in his study of impact of electronic communications on science communication process in South Africa. Observed that computer self-efficacy is a better predictor of performance than actual capability because a person's judgement based on prior experience often determines how he will use the skills and knowledge they have in specific domain. It is germane to know that computer self-efficacy is not a static concept; it is continually being actualised in an individual's mind, which Bandura refers to as "mastery experience". For example, given the right technical infrastructure, if MBA students value their interpersonal skills and believe that they are capable of maintaining ICT competence by pursuing a goal to its logical conclusion, their computer self- efficacy in that area will likely contribute to positive academic performance.

The term facilitating conditions represents the degree to which an individual believes that an organisational and technical infrastructure exist to support the use of EIRs. Facilitating conditions covers definitions from perceived behavioural control (planned behavioural theory and decomposed planned behaviour theory) and adaptability from diffusion of innovation theory. It also involves the circumstances that an individual believes exist to support his/her activities, such as electronic resources usage (Zhang, Ye, \& Liu, 2011). 
Facilitating conditions as a construct was later adapted by Venkatesh et.al (2003) to establish its relationship with technology use. In this context, facilitating conditions is described as the extent to which MBA students believe that technical infrastructure such as computer facilities and Internet connectivity exists to enhance the use of EIRs. Furthermore, it has been argued by Venkatesh et.al (2003) that availability of the requisite infrastructural and technical support within a university system will in no small measure encourage the use of electronic resources. For example, Teo and Milutinovic (2015) employed subjective norms, use of electronic resources and facilitating conditions as external variables to the Technology Acceptance Model (TAM) to examine the intention to use e-resources among 313 students in Serbia. Findings revealed that positive correlations exist among intrinsic motivation, use of electronic resources, and facilitating conditions as predictors of behavioural intention to use EIRs.

Tabassum, Roknuzzaman and Islam (2015) critically examined factors influencing EIRs intention usage at East West University in Bangladesh. Questionnaire-based survey and observational methods were used to gather information from one hundred and twenty nine (129) users of the institution digital library system. The findings suggested that factors such as user's knowledge of search domain, quality of EIRs content, system characteristics and service quality influenced their behavioural intention to use EIRs. The study however recommended that technical, physical and intellectual infrastructure needed to be developed upon in order to facilitate the use of EIRs in the university library. More user-friendly interface was further recommended to keep users familiar with the terminology, consistence interface style and clear navigation flow.

Ahmadu (2013) analysed factors influencing students' behavioural intention to use EIRs at Pentecost University College Ghana. The author reviewed personal, institutional and technological as some of the factors influencing students' usage intention of EIRs in learning processes. The study concludes that students need positive attitude towards the use of educational technology so as to provide useful insight about the adoption and integration of e-resources into their learning processes. Students' academic development was also identified as one of the key factors for promoting integration of computers in information search.

\section{Significance of the Study}

The study will be of benefit to university managements and librarians in being proactive in developing relevant ICT policies and strategies toward effective and sustainable electronic collection development in Nigerian universities, as well as promoting the use of relevant electronic information resources by MBA students. Also, the study will stimulate not only the MBA students but researchers and university administrations on the need to work concertedly to improve the quality of research in federal universities in Nigeria and be competitive globally. The information provided in this study will add to the body of literature in Library and information science.

\section{Objective of the Study}

The specific objectives of this study are as follows:

i. to ascertain the behavioural intention of MBA students towards use of electronic information resources in Nigeria universities;

ii. to find out the level of computer self-efficacy of MBA students towards use of electronic information resources in Nigeria universities;

iii. to investigate the facilitating conditions of electronic information resources use by MBA students in Nigeria universities;

\section{Research Questions}

1. What is the behavioural intention of MBA students to use electronic information resources in Nigeria universities?

2. What is the level of computer self-efficacy of MBA students towards use of electronic information resources in Nigeria universities?

3. What are the facilitating conditions of electronic information resources use by MBA students in Nigeria universities?

\section{Hypotheses}

The following null hypotheses were tested in the study at 0.05 level of significance:

1. There is no significant relationship between computer self-efficacy and behavioural intention to use EIRs by MBA students in Nigeria universities.

2. There is no significant relationship between facilitating conditions and behavioural intention to use EIRs by MBA students in Nigeria universities.

\section{METHODOLOGY}


The research design adopted for the study was survey method with the use of questionnaire to collect data for the study. The population size of the study consisted of 1,015 MBA students in ten federal universities in Nigeria. Cluster sampling technique was used for the study and systematic sampling technique was used to select $60 \%$ of the total population of the MBA students across the 10 federal universities offering the programme based on probability and proportionate size. The $60 \%$ sample was on the basis of the large population of MBA students in Nigeria federal universities. The choice of $60 \%$ sampling fraction was in line with Hammed and Popoola (2006) that the sampling fraction for samples selected in a survey research must be, at least, up to sixty per cent before generalisation could be made on the population of study. The data were collated and analysed using Pearson Product Moment Correlation Analysis, Multiple Regression Analysis using Partial Lease Square Method (PLSEM), Mean, Standard Deviation and Percentages. CronbachAlpha method was used to establish the reliability coefficients of the scales. The measurement scale established the psychometric properties of Computer self-efficacy (0.93), Facilitating Conditions (0.90) and Behavioural intention to Use Electronic Information Resources (0.95).

Research question one: What is the behavioural intention of MBA students to use electronic information resources in Nigeria Universities?

Table 1: Behavioural Intention of MBA Students towards Use EIRs in Nigerian Universities

\begin{tabular}{|c|c|c|c|c|c|c|c|}
\hline $\mathbf{S} / \mathbf{N}$ & Items & NT & ST & $\mathbf{T}$ & VT & $\bar{x}$ & S.D \\
\hline 1 & $\begin{array}{l}\text { I intend to use electronic information resources for } \\
\text { my class work and assignment }\end{array}$ & $\begin{array}{l}41 \\
4.0 \% \\
\end{array}$ & $\begin{array}{l}101 \\
10.0 \% \\
\end{array}$ & $\begin{array}{l}403 \\
39.7 \% \\
\end{array}$ & $\begin{array}{l}470 \\
46.3 \% \\
\end{array}$ & 3.28 & 0.80 \\
\hline 2 & $\begin{array}{l}\text { I intend to continue using electronic resources to } \\
\text { for my academic work }\end{array}$ & $\begin{array}{l}116 \\
11.4 \% \\
\end{array}$ & $\begin{array}{l}86 \\
8.5 \% \\
\end{array}$ & $\begin{array}{l}328 \\
32.3 \%\end{array}$ & $\begin{array}{l}485 \\
47.8 \% \\
\end{array}$ & 3.16 & 1.00 \\
\hline 3 & $\begin{array}{l}\text { I intend to continue using electronic resources to } \\
\text { meet my information needs even after the } \\
\text { completion of my programme }\end{array}$ & $\begin{array}{l}117 \\
11.5 \%\end{array}$ & $\begin{array}{l}114 \\
11.2 \%\end{array}$ & $\begin{array}{l}300 \\
29.6 \%\end{array}$ & $\begin{array}{l}484 \\
47.7 \%\end{array}$ & 3.13 & 1.02 \\
\hline 4 & $\begin{array}{l}\text { I can predict that I would use electronic } \\
\text { information resources in the text one month }\end{array}$ & $\begin{array}{l}87 \\
8.6 \% \\
\end{array}$ & $\begin{array}{l}143 \\
14.1 \%\end{array}$ & $\begin{array}{l}359 \\
35.4 \%\end{array}$ & $\begin{array}{l}426 \\
42.0 \%\end{array}$ & 3.11 & 0.94 \\
\hline 5 & $\begin{array}{l}\text { I would also recommend electronic information } \\
\text { resources to my colleagues for their academic work }\end{array}$ & $\begin{array}{l}122 \\
12.0 \%\end{array}$ & $\begin{array}{l}107 \\
10.5 \%\end{array}$ & $\begin{array}{l}324 \\
31.9 \%\end{array}$ & $\begin{array}{l}462 \\
45.5 \%\end{array}$ & 3.11 & 1.02 \\
\hline 6 & $\begin{array}{l}\text { If my library provides use electronic information } \\
\text { resources I expect that I will use them }\end{array}$ & $\begin{array}{l}121 \\
11.9 \%\end{array}$ & $\begin{array}{l}105 \\
10.3 \%\end{array}$ & $\begin{array}{l}334 \\
32.9 \%\end{array}$ & $\begin{array}{l}455 \\
44.8 \%\end{array}$ & 3.11 & 1.01 \\
\hline 7 & $\begin{array}{l}\text { I will try to use electronic information resources as } \\
\text { often as possible }\end{array}$ & $\begin{array}{l}112 \\
11.0 \% \\
\end{array}$ & $\begin{array}{l}122 \\
12.0 \% \\
\end{array}$ & $\begin{array}{l}323 \\
31.8 \% \\
\end{array}$ & $\begin{array}{l}458 \\
45.1 \% \\
\end{array}$ & 3.11 & 1.00 \\
\hline 8 & $\begin{array}{l}\text { I intend to frequently use electronic information } \\
\text { resources for my academic work }\end{array}$ & $\begin{array}{l}138 \\
13.6 \%\end{array}$ & $\begin{array}{ll}113 \\
11.1 \%\end{array}$ & $\begin{array}{l}281 \\
27.7 \%\end{array}$ & $\begin{array}{ll}483 \\
47.6 \%\end{array}$ & 3.09 & 1.06 \\
\hline 9 & $\begin{array}{l}\text { Whenever possible, I intend to use electronic } \\
\text { information resources as often as needed }\end{array}$ & $\begin{array}{l}125 \\
12.3 \% \\
\end{array}$ & $\begin{array}{l}109 \\
10.7 \% \\
\end{array}$ & $\begin{array}{l}327 \\
32.2 \% \\
\end{array}$ & $\begin{array}{l}454 \\
44.7 \% \\
\end{array}$ & 3.09 & 1.02 \\
\hline 10 & $\begin{array}{l}\text { I plan to use electronic information resources in the } \\
\text { next one month }\end{array}$ & $\begin{array}{l}153 \\
15.1 \%\end{array}$ & $\begin{array}{l}104 \\
10.2 \%\end{array}$ & $\begin{array}{l}285 \\
28.1 \%\end{array}$ & $\begin{array}{l}473 \\
46.6 \%\end{array}$ & 3.06 & 1.08 \\
\hline
\end{tabular}

Key: NT = Not True, ST= Sometimes True, $T=$ True, VT= Very True

The summary of behavioural intention of MBA students to use electronic information resources in Nigeria Universities is presented in Table 1. The ranking (using mean and standard deviation) of behavioural intention of MBA students to use EIRs in the table as perceived by the respondents shows that intention to use electronic information resources for class work and assignment was ranked highest by a mean score rating of $(\bar{x}=3.28)$, and was followed in succession by intention to continue using electronic resources to for academic work $(\bar{x}=3.16)$, intention to continue using electronic resources for information needs even after the completion MBA programme $(\bar{x}=3.13)$, prediction of electronic information resources use in the text one month $(\bar{x}=3.11)$, recommending electronic information resources to colleagues for academic work $(\bar{x}=3.11)$, use electronic information resources if provided by the library $(\bar{x}=3.11)$, use of electronic information resources as often as possible $(\bar{x}=3.11)$, intention to frequently use electronic information resources for academic work $(\bar{x}=3.09)$, intention to use electronic information resources as often as needed $(\bar{x}=3.09)$ and lastly, planning to use electronic information resources in the next one month $(\bar{x}=3.06)$ respectively.

Hence, the major contributors to behavioural intention to use of EIRs by MBA students are; using EIRs for class work and assignment, academic work, and information needs even after the completion of programme, while the least 
contributor to behavioural intention was planning to use EIRs in the next one month. Generally, one could conclude that the respondents have good behavioural intention to use EIRs.

Research question two: What is the level of computer self-efficacy of MBA students towards use of electronic information resources in Nigeria universities?

Table 2: Computer Self-efficacy of EIRs use by MBA Students in Federal Universities in Nigeria

\begin{tabular}{|c|c|c|c|c|c|c|c|}
\hline $\mathbf{s} / \mathbf{n}$ & Computer self-efficacy & SD & $\mathbf{D}$ & $\mathbf{A}$ & SA & $\bar{x}$ & S.D \\
\hline 1 & $\begin{array}{l}\text { I have the knowledge to use electronic information } \\
\text { resources }\end{array}$ & $\begin{array}{l}125 \\
12.3 \%\end{array}$ & $\begin{array}{l}64 \\
6.3 \%\end{array}$ & $\begin{array}{l}263 \\
25.9 \%\end{array}$ & $\begin{array}{l}563 \\
55.5 \%\end{array}$ & 3.25 & 1.03 \\
\hline 2 & $\begin{array}{l}\text { I do not feel nervous at all when using electronic } \\
\text { information }\end{array}$ & $\begin{array}{l}98 \\
9.7 \%\end{array}$ & $\begin{array}{l}82 \\
8.1 \%\end{array}$ & $\begin{array}{l}309 \\
30.4 \%\end{array}$ & $\begin{array}{l}526 \\
51.8 \%\end{array}$ & 3.24 & 0.96 \\
\hline 3 & $\begin{array}{l}\text { I find it very convenient to use electronic } \\
\text { information resources }\end{array}$ & $\begin{array}{l}109 \\
10.7 \%\end{array}$ & $\begin{array}{l}87 \\
8.6 \%\end{array}$ & $\begin{array}{l}295 \\
29.1 \%\end{array}$ & $\begin{array}{l}524 \\
51.6 \%\end{array}$ & 3.22 & 0.99 \\
\hline 4 & $\begin{array}{l}\text { I am able to confidently use electronic information } \\
\text { resources }\end{array}$ & $\begin{array}{l}137 \\
13.5 \%\end{array}$ & $\begin{array}{l}61 \\
6.0 \%\end{array}$ & $\begin{array}{l}271 \\
26.7 \%\end{array}$ & $\begin{array}{l}546 \\
53.8 \%\end{array}$ & 3.21 & 1.05 \\
\hline 5 & I feel confident organizing and managing files & $\begin{array}{l}105 \\
10.3 \%\end{array}$ & $\begin{array}{l}83 \\
8.2 \%\end{array}$ & $\begin{array}{l}322 \\
31.7 \%\end{array}$ & $\begin{array}{l}505 \\
49.8 \%\end{array}$ & 3.21 & 0.97 \\
\hline 6 & I feel confident moving the cursor on the monitor & $\begin{array}{l}112 \\
11.0 \%\end{array}$ & $\begin{array}{l}84 \\
8.3 \%\end{array}$ & $\begin{array}{l}302 \\
29.8 \%\end{array}$ & $\begin{array}{l}517 \\
50.9 \%\end{array}$ & 3.21 & 1.00 \\
\hline 7 & $\begin{array}{l}\text { I use electronic information resources at my } \\
\text { convenience }\end{array}$ & $\begin{array}{l}103 \\
10.1 \%\end{array}$ & $\begin{array}{l}79 \\
7.8 \%\end{array}$ & $\begin{array}{l}350 \\
34.5 \%\end{array}$ & $\begin{array}{l}483 \\
47.6 \%\end{array}$ & 3.20 & 0.96 \\
\hline 8 & $\begin{array}{l}\text { I feel confident using a printer to make hard copy } \\
\text { of document }\end{array}$ & $\begin{array}{l}105 \\
10 . \%\end{array}$ & $\begin{array}{l}84 \\
8.3 \%\end{array}$ & $\begin{array}{ll}330 \\
32.5 \%\end{array}$ & $\begin{array}{l}496 \\
48.9 \%\end{array}$ & 3.20 & 0.97 \\
\hline 9 & I feel confident using the computer to analyse data & $\begin{array}{l}97 \\
9.6 \% \\
\end{array}$ & $\begin{array}{l}85 \\
8.4 \%\end{array}$ & $\begin{array}{l}357 \\
35.2 \%\end{array}$ & $\begin{array}{l}476 \\
46.9 \% \\
\end{array}$ & 3.19 & 0.95 \\
\hline 10 & I feel confident using internet and e-mail & $\begin{array}{l}106 \\
10.4 \% \\
\end{array}$ & $\begin{array}{l}97 \\
9.6 \% \\
\end{array}$ & $\begin{array}{l}315 \\
31.0 \% \\
\end{array}$ & $\begin{array}{l}497 \\
49.0 \% \\
\end{array}$ & 3.19 & 0.98 \\
\hline 11 & $\begin{array}{l}\text { I have the ability to use electronic information } \\
\text { resources }\end{array}$ & $\begin{array}{l}131 \\
12.9 \%\end{array}$ & $\begin{array}{l}88 \\
8.7 \%\end{array}$ & $\begin{array}{l}263 \\
25.9 \%\end{array}$ & $\begin{array}{l}533 \\
52.5 \%\end{array}$ & 3.18 & 1.05 \\
\hline 12 & $\begin{array}{l}\text { I have control over using electronic information } \\
\text { resources }\end{array}$ & $\begin{array}{l}121 \\
11.9 \%\end{array}$ & $\begin{array}{l}88 \\
8.7 \%\end{array}$ & $\begin{array}{ll}308 \\
30.3 \%\end{array}$ & $\begin{array}{l}498 \\
49.1 \%\end{array}$ & 3.17 & 1.01 \\
\hline 13 & $\begin{array}{l}\text { If I wanted to I could use electronic information } \\
\text { resources }\end{array}$ & $\begin{array}{l}99 \\
9.8 \%\end{array}$ & $\begin{array}{l}97 \\
9.6 \%\end{array}$ & $\begin{array}{l}350 \\
34.5 \%\end{array}$ & $\begin{array}{l}469 \\
46.2 \%\end{array}$ & 3.17 & 0.96 \\
\hline 14 & $\begin{array}{l}\text { I feel confident using the users' guide when help in } \\
\text { needed }\end{array}$ & $\begin{array}{l}106 \\
10.4 \%\end{array}$ & $\begin{array}{l}98 \\
9.7 \%\end{array}$ & $\begin{array}{ll}329 \\
32.4 \%\end{array}$ & $\begin{array}{l}482 \\
47.5 \%\end{array}$ & 3.17 & 0.98 \\
\hline 15 & I feel confident entering and saving data into a file & $\begin{array}{l}110 \\
10.8 \%\end{array}$ & $\begin{array}{l}97 \\
9.6 \%\end{array}$ & $\begin{array}{l}315 \\
31.0 \%\end{array}$ & $\begin{array}{l}493 \\
48.6 \%\end{array}$ & 3.17 & 0.99 \\
\hline 16 & $\begin{array}{l}\text { I feel confident understanding terms/words relating } \\
\text { to computer hardware and software }\end{array}$ & $\begin{array}{l}115 \\
11.3 \% \\
\end{array}$ & $\begin{array}{ll}103 \\
10.1 \% \\
\end{array}$ & $\begin{array}{l}289 \\
28.5 \% \\
\end{array}$ & $\begin{array}{l}508 \\
50.0 \%\end{array}$ & 3.17 & 1.01 \\
\hline 17 & $\begin{array}{l}\text { I have a good knowledge of power point } \\
\text { presentation }\end{array}$ & $\begin{array}{l}105 \\
10.3 \% \\
\end{array}$ & $\begin{array}{l}108 \\
10.6 \% \\
\end{array}$ & $\begin{array}{l}324 \\
31.9 \% \\
\end{array}$ & $\begin{array}{l}478 \\
47.1 \% \\
\end{array}$ & 3.16 & 0.98 \\
\hline 18 & $\begin{array}{l}\text { It is mostly up to me whether or not I use } \\
\text { electronic information resources }\end{array}$ & $\begin{array}{l}104 \\
10.2 \%\end{array}$ & $\begin{array}{l}88 \\
8.7 \% \\
\end{array}$ & $\begin{array}{l}377 \\
37.1 \% \\
\end{array}$ & $\begin{array}{l}446 \\
43.9 \% \\
\end{array}$ & 3.15 & 0.96 \\
\hline 19 & I feel confident working on a personal computer & $\begin{array}{l}106 \\
10.4 \%\end{array}$ & $\begin{array}{l}113 \\
11.1 \%\end{array}$ & $\begin{array}{l}317 \\
31.2 \%\end{array}$ & $\begin{array}{l}479 \\
47.2 \%\end{array}$ & 3.15 & 0.99 \\
\hline 20 & I have a good knowledge of desktop publishing & $\begin{array}{l}130 \\
12.8 \%\end{array}$ & $\begin{array}{l}92 \\
9.1 \%\end{array}$ & $\begin{array}{l}312 \\
30.7 \%\end{array}$ & $\begin{array}{l}481 \\
47.4 \%\end{array}$ & 3.13 & 1.03 \\
\hline 21 & $\begin{array}{l}\text { My academic work demands that I use electronic } \\
\text { information resources }\end{array}$ & $\begin{array}{l}121 \\
11.9 \%\end{array}$ & $\begin{array}{l}86 \\
8.5 \%\end{array}$ & $\begin{array}{ll}358 \\
35.3 \%\end{array}$ & $\begin{array}{l}450 \\
44.3 \%\end{array}$ & 3.12 & 1.00 \\
\hline 22 & I have a good knowledge of database management & $\begin{array}{l}120 \\
11.8 \%\end{array}$ & $\begin{array}{l}111 \\
10.9 \%\end{array}$ & $\begin{array}{ll}342 \\
33.7 \%\end{array}$ & $\begin{array}{l}442 \\
43.5 \%\end{array}$ & 3.09 & 1.01 \\
\hline
\end{tabular}

\section{Key: SD = Strongly Disagree, D = Disagree, A = Agree, SA = Strongly Agree}

Table 2 present the results of perceived behavioural control (Computer Self-efficacy) of MBA students towards use of electronic information resources in Nigeria. The descriptive analysis of frequency and percentages are hereby highligted. $81.4 \%$ of the respondents agreed that they have the knowledge to use electronic information resources, while $82.2 \%$ were of the opinion that they do not feel nervous at all when using electronic information, The result further reveals that, $80.7 \%$ of the respondents ascertained that they find it very convenient to use electronic information resources. Whereas $80.5 \%$ 
supported the ideal that they are able to confidently use electronic information resources and $81.5 \%$ of the respondents posited that they feel confident organising and managing files. Also, $80.7 \%$ of them agreed that they feel confident moving the cursor on the monitor. $82.1 \%$ of the agreed that they use electronic information resources at my convenience, in addition, $81.4 \%$ opined that they I feel confident using a printer to make hard copy of document, and $82.1 \%$ of them agreed that they feel confident using the computer to analyse data, the result further indicates that $80 \%$ of them agreed that they feel confident using internet and e-mail, and $78.4 \%$ noted that they have the ability to use electronic information resources. Also, 79.4\% agreed that they have control over using electronic information resources, whereas $80.7 \%$ of the respondents agreed that If they wanted to, they could use electronic information resources, and $79.9 \%$ of them agreed that they feel confident using the users' guide when help in needed, while $79.6 \%$ of the respondents ascertained that they feel confident entering and saving data into a file, also, $78.5 \%$ of them agreed that they feel confident understanding terms/words relating to computer hardware and software. In addition, $79 \%$ of the respondents averred that they have a geed knowledge of power point presentation, and $81 \%$ agreed that It is mostly up to them whether or not they use electronic information resources, the result further shows that $78.4 \%$ noted that they feel confident working on a personal computer, and $78.1 \%$ of the respondents agreed that they have a good knowledge of desktop publishing, also, 79.6\% agreed that their academic work demands that they use electronic information resources. Lastly, 77.2\% were of the opinion that they have good knowledge of database management.

The result in Table 4.14 further revealed the mean of perceived behavioural control (computer self-efficacy) of MBA students towards use of electronic information resources in Nigeria. It shows that knowledge to use electronic information resources $(\bar{x}=3.25)$ was ranked highest by the mean score rating and was followed in succession by not feeling nervous when using electronic information $(\bar{x}=3.24)$, finding it very convenient to use electronic information resources $(\bar{x}=$ $3.22)$, ability to confidently use electronic information resources $(\bar{x}=3.21)$, confidence in organizing and managing files $(\bar{x}=3.21)$, confidence in moving the cursor on the monitor $(\bar{x}=3.21)$, use of electronic information resources at convenience $(\bar{x}=3.20)$, confidence using a printer to make hard copy of document $(\bar{x}=3.20)$, confidence in using the computer to analyse data $(\bar{x}=3.19)$, proficiency in using internet and e-mail $(\bar{x}=3.19)$, ability to use electronic information resources $(\bar{x}=3.18)$, having control over using electronic information resources $(\bar{x}=3.17)$, using electronic information resources at volition $(\bar{x}=3.17)$, confidence in using the users' guide when help in needed $(\bar{x}=3.17)$, confidence in entering and saving data into a file $(\bar{x}=3.17)$, ability to understand terms/words relating to computer hardware and software $(\bar{x}=3.17)$, knowledge of power point presentation $(\bar{x}=3.16)$, the decision to use electronic information resources is personal $(\bar{x}=3.15)$, having confidence working on a personal computer $(\bar{x}=3.15)$ knowledge of desktop publishing $(\bar{x}=3.13)$, academic work demands the use electronic information resources $(\bar{x}=3.12)$ and lastly, good knowledge of database management $(\bar{x}=3.09)$ respectively.

Table 2.1: $\quad$ Test of norm showing the level of Computer self-efficacy of MBA Students towards Use of Electronic Information Resources in Nigeria

\begin{tabular}{|l|l|l|l|l|}
\hline Interval & Mean index & $\begin{array}{l}\text { Level of Computer Self- } \\
\text { efficacy }\end{array}$ & Frequency & Percentage \\
\hline High & $\mathbf{6 9 . 9 3}$ & High & 799 & 78.7 \\
\hline Moderate & & Moderate & 169 & 16.7 \\
\hline Low & & Low & 47 & 4.6 \\
\hline
\end{tabular}

Table 2.1 shows the level of computer self-efficacy of MBA students towards use of electronic information resources in Nigeria. 47(4.6\%) students had low level computer self-efficacy, 169(16.7) students had moderate level of computer selfefficacy and 799(78.7\%) had high level of computer self-efficacy. Therefore, the level of computer self-efficacy of MBA students towards use of electronic information resources in Nigeria is high. 
Research question three: What are the facilitating conditions of electronic information resources use by MBA students in Nigeria universities?

Table 3: Facilitating Conditions of EIRs use by MBA Students in Federal Universities in Nigeria.

\begin{tabular}{|c|c|c|c|c|c|c|c|}
\hline $\mathrm{S} / \mathrm{N}$ & Facilitating conditions & SD & D & $\mathbf{A}$ & SA & $\bar{x}$ & S.D \\
\hline 1 & $\begin{array}{l}\text { There is sufficient and competent manpower to } \\
\text { restore internet access in the event of system } \\
\text { breakdown }\end{array}$ & $\begin{array}{l}117 \\
11.5 \%\end{array}$ & $\begin{array}{l}109 \\
10.7 \%\end{array}$ & $\begin{array}{l}352 \\
34.7 \%\end{array}$ & $\begin{array}{l}437 \\
43.1 \%\end{array}$ & 3.09 & 1.00 \\
\hline 2 & $\begin{array}{l}\text { there is availability of ICT equipment in my } \\
\text { university }\end{array}$ & $\begin{array}{ll}114 \\
11.2 \%\end{array}$ & $\begin{array}{ll}138 \\
13.6 \%\end{array}$ & $\begin{array}{ll}337 \\
33.2 \%\end{array}$ & $\begin{array}{ll}426 \\
42.0 \%\end{array}$ & 3.06 & 1.00 \\
\hline 3 & $\begin{array}{l}\text { Available electronic information resources does not } \\
\text { adequately support my teaching and research } \\
\text { endeavours }\end{array}$ & $\begin{array}{l}153 \\
15.1 \%\end{array}$ & $\begin{array}{l}145 \\
14.3 \%\end{array}$ & $\begin{array}{l}306 \\
30.1 \%\end{array}$ & $\begin{array}{l}411 \\
40.5 \%\end{array}$ & 2.96 & 1.07 \\
\hline 4 & $\begin{array}{l}\text { The use of electronic information resources is not } \\
\text { encouraged in my institution }\end{array}$ & $\begin{array}{l}156 \\
15.4 \%\end{array}$ & $\begin{array}{l}161 \\
15.9 \%\end{array}$ & $\begin{array}{l}299 \\
29.5 \%\end{array}$ & $\begin{array}{l}399 \\
39.3 \%\end{array}$ & 2.93 & 1.08 \\
\hline 5 & $\begin{array}{l}\text { There is no provision of periodical training } \\
\text { programme on the use of electronic information } \\
\text { resources in my institution }\end{array}$ & $\begin{array}{l}169 \\
16.7 \%\end{array}$ & $\begin{array}{l}154 \\
15.2 \%\end{array}$ & $\begin{array}{l}331 \\
32.6 \%\end{array}$ & $\begin{array}{l}361 \\
35.6 \%\end{array}$ & 2.87 & 1.08 \\
\hline 6 & $\begin{array}{l}\text { There is central support unit in my institution to } \\
\text { help with technical problems }\end{array}$ & $\begin{array}{l}164 \\
16.2 \%\end{array}$ & $\begin{array}{l}193 \\
19.0 \%\end{array}$ & $\begin{array}{l}311 \\
30.6 \%\end{array}$ & $\begin{array}{l}347 \\
34.2 \%\end{array}$ & 2.83 & 1.07 \\
\hline 7 & $\begin{array}{l}\text { Internet connectivity in my institution does not } \\
\text { motivate me to use electronic information } \\
\text { resources }\end{array}$ & $\begin{array}{l}168 \\
16.6 \%\end{array}$ & $\begin{array}{l}201 \\
19.8 \%\end{array}$ & $\begin{array}{l}344 \\
33.9 \%\end{array}$ & $\begin{array}{l}302 \\
29.8 \%\end{array}$ & 2.77 & 1.05 \\
\hline 8 & $\begin{array}{l}\text { There is availability of constant electricity to power } \\
\text { ICT equipment in my university }\end{array}$ & $\begin{array}{l}192 \\
18.9 \% \\
\end{array}$ & $\begin{array}{l}201 \\
19.8 \% \\
\end{array}$ & $\begin{array}{l}309 \\
30.4 \% \\
\end{array}$ & $\begin{array}{l}313 \\
30.8 \% \\
\end{array}$ & 2.73 & 1.09 \\
\hline 9 & $\begin{array}{l}\text { Available technical infrastructure are ineffective } \\
\text { and grossly inadequate }\end{array}$ & $\begin{array}{ll}204 \\
20.1 \%\end{array}$ & $\begin{array}{ll}231 \\
22.8 \%\end{array}$ & $\begin{array}{ll}336 \\
33.1 \%\end{array}$ & $\begin{array}{l}244 \\
24.0 \%\end{array}$ & 2.61 & 1.06 \\
\hline 10 & $\begin{array}{l}\text { The equipment provided in my institution are not } \\
\text { compatible with the computer I use }\end{array}$ & $\begin{array}{l}229 \\
22.6 \%\end{array}$ & $\begin{array}{l}194 \\
19.1 \%\end{array}$ & $\begin{array}{l}338 \\
33.3 \%\end{array}$ & $\begin{array}{l}254 \\
25.0 \%\end{array}$ & 2.61 & 1.09 \\
\hline 11 & $\begin{array}{l}\text { I do not use electronic information resources due to } \\
\text { incessant technical challenges }\end{array}$ & $\begin{array}{l}251 \\
24.7 \%\end{array}$ & $\begin{array}{l}208 \\
20.5 \%\end{array}$ & $\begin{array}{l}305 \\
30.0 \%\end{array}$ & $\begin{array}{l}251 \\
24.7 \%\end{array}$ & 2.55 & 1.11 \\
\hline
\end{tabular}

\section{Key: SD = Strongly Disagree, D = Disagree, A = Agree, SA = Strongly Agree}

Table 3 present the results of perceived behavioural control (Facilitating Conditions) of MBA students towards use of electronic information resources in Nigeria. The descriptive analysis of frequency and percentages are hereby highligted. $77.8 \%$ of the respondents agreed that there is sufficient and competent manpower to restore internet access in the event of system breakdown , while $75.2 \%$ were of the opinion that there is availability of ICT equipment in their universities, The result further reveals that, $70.6 \%$ of the respondents ascertained that available electronic information resources does not adequately support their teaching and research endeavours. Whereas $68.8 \%$ supported the ideal that the use of electronic information resources is not encouraged in my institution and $68.2 \%$ of the respondents posited that there is no provision of periodical training programme on the use of electronic information resources in their institutions. Also, 64.8\% of them agreed that there is central support unit their institutions to help with technical problems. $63.7 \%$ of them agreed that internet connectivity in their institutions does not motivate them to use electronic information resources, in addition, $61.2 \%$ opined that there is availability of constant electricity to power ICT equipment in their universities, also, $57.1 \%$ of the respondents agreed that available technical infrastructure are ineffective and grossly inadequate, the result further shows that $58.3 \%$ of them supported the idea of the equipment provided in their institutions are not compatible with the computers they use, lastly, $54.7 \%$ of the respondents agreed that they do not use electronic information resources due to incessant technical challenges.

The result in Table 4.16 further revealed the mean of perceived behavioural control (facilitating conditions) of MBA students towards use of electronic information resources in Nigeria. It shows that; sufficient and competent manpower to restore internet access in the event of system breakdown $(\bar{x}=3.09)$ was ranked highest as the main facilitating condition and was followed by availability of ICT equipment in the surveyed universities $(\bar{x}=3.06)$, adequacy of electronic information resources to support teaching and research $(\bar{x}=2.96)$, institutional support and encouragement to use of electronic information resources $(\bar{x}=2.93)$, provision of periodical training programme on the use of electronic 
information resources $(\bar{x}=2.87)$, availability of central support unit to help with technical problems $(\bar{x}=2.83)$, poor internet connectivity does not encourage use electronic information resources $(\bar{x}=2.77)$, availability of constant electricity to power ICT equipment in the surveyed universities $(\bar{x}=2.73)$, available technical infrastructure are ineffective and grossly inadequate $(\bar{x}=2.61)$, lack of compatibility of computer hardwares $(\bar{x}=2.61)$ and lastly, not using electronic information resources due to incessant technical challenges $(\bar{x}=2.55)$ respectively.

Table 3.1: $\quad$ Test of norm showing the Level of Facilitating Conditions of EIRs by MBA Students in Nigeria Universities

\begin{tabular}{|l|l|l|l|l|}
\hline Interval & Mean index & $\begin{array}{l}\text { Level of facilitating } \\
\text { conditions }\end{array}$ & Frequency & Percentage \\
\hline High & $\mathbf{3 1 . 0 1}$ & High & 602 & 59.3 \\
\hline Moderate & & Moderate & 384 & 37.8 \\
\hline Low & & Low & 29 & 2.9 \\
\hline
\end{tabular}

Table 4.17 shows the level of facilitating conditions of EIRs by MBA students in Nigeria universities. 29(2.9\%) students indicated low level of facilitating conditions, 384(37.8) students indicated moderate level facilitating conditions and $602(59.3 \%)$ indicated high level facilitating conditions. Therefore, the level of facilitating conditions of EIRs by MBA students in Nigeria universities is high.

Hypothesis: There is no significant relationship between perceived behavioural control (computer self-efficacy and facilitating conditions) and behavioural intention to use electronic information resources among MBA students in Nigeria universities.

Table 4: $\quad$ Pearson Product Moment Correlation (PPMC) showing the relationship between perceived behavioural control (computer self-efficacy and facilitating conditions) of EIRs and behavioural intention to use of electronic information resources

\begin{tabular}{|l|l|l|l|l|l|l|}
\hline Variable & Mean & Std. Dev. & n & r & Sig. P & Remark \\
\hline Perceived behavioural control & 100.93 & 22.31 & & .276 & .000 & \\
Computer self-efficacy & 69.93 & 17.40 & & .269 & .000 & \\
Facilitating conditions & 31.01 & 7.48 & 1015 & .198 & .000 & Sig. \\
Behavioural intention to use EIRs & 31.23 & 7.74 & & & & \\
& & & & & & \\
\hline
\end{tabular}

* Sig. at 0.05 level

It is shown in table 4 that there is significant relationship between perceived behavioural control $(r=.276, n=1015, p(.000)$ $<0.05)$, computer self-efficacy $(\mathrm{r}=.269, \mathrm{n}=1015$, $\mathrm{p}(.000)$, facilitating conditions $(\mathrm{r}=.198, \mathrm{n}=1015, \mathrm{p}(.000)<0.05)$ of EIRs and behavioural intention to use of electronic information resources.

Hence, it could be deduced that perceived behavioural control (computer self-efficacy and facilitating conditions) of electronic information resources positively influenced behavioural intention to use of EIRs in the study.

The hypothesis is rejected.

\section{DISCUSSION OF THE FINDINGS}

\section{Behavioural Intention of MBA Students towards the Use of Electronic Information Resources}

The analysis of the data on behavioural intention of MBA students towards the use of electronic information resources revealed that only three (major contributors) of the 10 variables in the behavioural intention scale were above the mean score of 3.13. These were 'I intend to use electronic information resources for my class work and assignment' with mean score of 3.28, 'I intend to continue using electronic resources for my academic work' with mean score of 3.16 and 'I intend to continue using electronic resources to meet my information needs even after the completion of my programme' which has 3.13 as mean score. The data on the behavioural intention of MBA students to use EIRs has revealed a high level of usage intentions with the overall mean of 3.13. The findings is in line with Erasmus, Rothmann, and Eeden (2015) who used structural model with a cross-sectional survey design to test technology acceptance among South African teachers. They confirmed that there are significant paths from perceived usefulness of the information system to behavioural intentions to use it. Furthermore, they submitted that behavioural intention to use a system predicted actual use thereof. In the same vein, Sinh and Nhung (2012) argued that users' behavioural intention will influence the use of EIRs. Thus, in a survey on searching behaviour of users of six online databases subscribed to by the Central Vietnam National University in 2012 reported that $87.5 \%$ requested for full-text articles as compared with $12.5 \%$ who requested for abstracts. 


\section{Computer Self-efficacy of EIRs use by MBA Students}

Perceived behavioural control (computer self-efficacy) of EIRs by MBA students in this study was strong as indicated with an overall mean score of 3.18. Strength refers to the confidence possessed by MBA students in their ability in various computing tasks and their sense of judgment to organise and execute causes of action required to attain designated computing goals. Computer self-efficacy predicts intentions to use a wide range of technologically advanced products. Thus, MBA students' perceived behavioural control and skills in using EIRs could affect his behavioural intention to use and actual use of EIRs. This is because the student is comfortable with using the innovation. It is assumed that MBA students with a strong sense of computer self-efficacy will be able to adapt and be competent in the use of EIRs and will be able to adapt in their learning and research activities in the university system. But those who are beset with low computer self-efficacy will suffer physical and emotional strain (Bandura, 1996). It was concluded that the stronger the computer self- efficacy, the more likely will the person pursue challenging computing tasks, persist on them and perform them successfully and competently. A MBA student individual may have high computer self-efficacy in using the Internet but low computer self-efficacy when asked to design a database.

The findings of this study is supported by Smith (2011), in his study of impact of electronic communications on science communication process in South Africa. Observed that computer self-efficacy is a better predictor of performance than actual capability because a person's judgement based on prior experience often determines how he will use the skills and knowledge they have in specific domain. It is germane to know that computer self-efficacy is not a static concept; it is continually being actualised in an individual's mind, which Bandura refers to as "mastery experience". For example, given the right technical infrastructure, if MBA students value their interpersonal skills and believe that they are capable of maintaining ICT competence by pursuing a goal to its logical conclusion, their computer self- efficacy in that area will likely contribute to positive academic performance; that is why computer self-efficacy is seen as being a better predictor of behavioural intention to use EIRs.

Sam, Othman, and Nording, (2011) in their study on computer self-efficacy, computer anxiety and attitude towards the internet among undergraduates in UNIMAS observed that frequency of use is a factor that has a bearing on computer self-efficacy. An individual's computer self- efficacy toward an application can decline during periods of inactivity with that particular application. Similarly, frequency of use is likely to increase computer self-efficacy because the more you use a computer system the better you are. Sam et.al (2011) observed that, since computer self-efficacy refers to a person's perception of his computing ability, fundamentally, this suggests that a person's perception of his ability in certain tasks can very much depend on whom they are comparing themselves with and the past experiences with computer tasks.

\section{Facilitating Conditions of EIRs Use by MBA Students}

The outcome of the analysis on perceived behavioural control (facilitating conditions) of EIRs use by MBA students in the surveyed universities shows that these facilities exist in the selected institutions. The findings in this study reveal an overall mean score of 2.28. In the eleven variables on facilitating conditions of EIRs, six were above the 2.28 overall mean while five variables were below. This indicates that the facilitating conditions of EIRs were marginally high. Majority of the respondents agreed that availability of the requisite infrastructural and technical support within a system will go a long way to encourage the use of electronic resources. The findings agreed with the position of Teo and Milutinovic (2015) that employed subjective norm, knowledge of mathematics, and facilitating conditions as external variables to the Technology Acceptance Model (TAM) to examine the intention to use e-resources for teaching mathematics among pre-service teachers in Serbia. Structural equation model was used to analyse data gathered from the survey of 313 participants. The analysis revealed that the proposed model in this study has a good fit and accounted for $5.4 \%$ of the variance in the behavioural intention to use e-resources. The results show that facilitating conditions have a significant influence on pre-service teachers' perceived usefulness and perceived ease of use of EIRs. The authors submitted that if pre-service teachers perceive EIRs to be useful and easy to use in the presence of technical support, their actual use of the resources would be influenced.

Supporting the finding that facilitating conditions are significant to the use of EIRs is Tabassum, Roknuzzaman and Islam (2015) who critically examined factors influencing EIRs intention usage at East West University in Bangladesh. Questionnaire-based survey and observational methods were used to gather information from one hundred and twenty nine (129) users of the institution digital library system. The findings suggested that factors such as user's knowledge of search domain, quality of EIRs content, system characteristics and service quality influenced their behavioural intention to use EIRs. The study however recommended that technical infrastructure needed to be developed upon in order to facilitate the use of EIRs in the university library. He also noted that more user-friendly interface was needed to keep users familiar with the terminology, consistence interface style and clear navigation flow.

Ahmadu (2013) analysed factors influencing students' behavioural intention to use EIRs at Pentecost University College Ghana. The author reviewed personal, institutional and technological issues as some of the factors influencing students' usage intention of EIRs in learning processes. The study concludes that students need the right facilitating 
conditions to use of educational technology so as to provide useful insight about the adoption and integration of e-resources into their learning processes. Students' academic development was also identified as one of the key factors for promoting integration of computers in information search.

Afshari, Abu Bakar, Luan, Abu Samah and Fooi (2009) examined non-manipulative and manipulative factors influencing the behavioural intention of postgraduate students to use EIRs. The researchers noted that the success of eresources usage is not dependent on the availability or absence of one individual factor, but is determined through a dynamic process involving a set of interrelated factors. It was suggested that constant training must be provided for these students to model the new pedagogies and tools for learning with the aim of enhancing their academic performance. The study further suggested that, it is important for librarians and policy makers to understand the factors affecting effectiveness and cost-effectiveness of different approaches to EIRs use by students. They also noted that availability of electronic resources in a library plays a prominent role in facilitating usage intention of the required information by the user in a convenient manner.

\section{Relationship between Perceived Behavioural Control (computer self-efficacy and facilitating conditions) of EIRs and Behavioural Intention to Use EIRs in Nigeria Universities.}

The findings of the study revealed a positive relationship between perceived behavioural control of electronic information resources and MBA students' behavioural intention to use electronic information resources in Nigeria Universities $(\mathrm{r}=.276, \mathrm{n}=1015, \mathrm{p}(.000)<0.05)$. With this result, hypothesis two states that "there is no significant relationship between perceived behavioural control (computer self-efficacy and facilitating conditions) of electronic information resources and behavioural intention to use electronic information resources among MBA students" was thus rejected.

According to the theory of planned behaviour, perceived behavioural control, together with behavioural intention, can be used directly to predict behavioural achievement such as the use of EIRs. At least two rationales can be offered for this hypothesis. First, holding intention constant, the effort expended to bring a course of behaviour to a successful conclusion is likely to increase with perceived behavioural control. For instance, if two MBA students have equally strong intentions to use EIRs, and both try to do so; the person who is confident of his search skills is more likely to persevere than the person who doubts his ability. The second reason for expecting a direct link between perceived behavioural control and behavioural achievement is that perceived behavioural control can often be used as a substitute for a measure of actual control. Whether a measure of perceived behavioural control can substitu te for a measure of actual control depends, of course, on the accuracy of the perceptions. Perceived behavioural control may not be particularly realistic when a person has relatively little information about EIRs, when requirements or available resources have changed, or when new and unfamiliar elements have entered into the situation. Under those conditions, a measure of perceived behavioural control may add little to accuracy of behavioural prediction. However, to the extent that perceived control is realistic, it can be used to predict the probability of a successful EIRs use (Ajzen, 2006).

The relative importance of intentions and perceived behavioural control in the prediction of EIRs use is expected to vary across situations. When the behaviour or situation affords a person complete control over EIRs use, intentions alone should be sufficient to predict EIRs use, as specified in the theory of reasoned action. The addition of perceived behavioural control should become increasingly useful as volitional control over the behavioural intention declines. Both, intentions and perceptions of behavioural control, can make significant contributions to the prediction of behavioural intention to use EIRs.

The result of this study is supported by studies carried out by Llody and Solak (2011) in their design of exemption test computer self-efficacy for postgraduate students in Pennsylvania U.S.A, Deng (2010) for students in India, and Yolande, Edwards and James (2015) for master students of the University of Iowa. These studies have stressed the importance of perceived behavioural control (computer self-efficacy) on the behavioural intention to use EIRs. The need for computer self-efficacy has become widely accepted as technological necessity of modern life. Several studies have demonstrated the effect of computer anxiety and computer self-efficacy on behavioural intention to use EIRs. Computer self-efficacy has been shown to be positively related to use EIRs. A student's confidence about computer skills may affect his intention to use internet resources. The less confident a student feels about computer skills, the less he or she desires to learn about computer technology and use of EIRs (Zhang \& Espinoza, 2008).

However, it has been argued that availability of the requisite infrastructural and technical support within a system will in no small way encourage the use of EIRs. Teo and Milutinovic (2015) employed subjective norm and facilitating conditions as external variables to the Technology Acceptance Model (TAM) to examine the intention to use EIRs among teachers in Serbia. Structural equation model was used to analyse data gathered from the survey of 313 participants. The analysis revealed that the proposed model in this study has a good fit and accounted for $5.4 \%$ of the variance in the behavioural intention to use EIRs. The results also show that facilitating conditions have a significant influence behavioural intention to use EIRs. 


\section{CONCLUSION AND RECOMMENDATIONS}

The results of the study was an indication that electronic information resources use plays a vital role in MBA students academic and research endeavours. The quality and advantages of EIRs in terms of access to information resources round the clock, research output availability and globally access through the use of electronic information resources, access to current and up-to-date information, access to quality literature, cheap cost of access and lastly, unhindered access to electronic information resources have necessitated the high level of use of EIRs by MBA students in Nigerian Universities. Although the benefits derived from using EIRs are not debatable; however, to sustain high level of use of EIRs by MBA students in Nigeria federal universities librarians and university management should work at providing alternative sources of power supply as a way of addressing the facilitating conditions affecting the use of EIRs. Since the results of this study indicated that computer self-efficacy of MBA students towards use of electronic information resources had significant influence on behavioural intention to use EIRs, concerted efforts should be made by the university management to introduce computer literacy programmes as part of their course work in order to address and improve on their behavioural intention to use EIRs.

\section{REFERENCES}

Afshari, M, Abu Bakar, K., Luan, W.S., Abu Samah, B. and Fooi, F. S. 2009. Factors affecting teachers' use of information and communication technology, International Journal of Instruction, 2.1:77-104

Ahmadu, S.M.Z. 2013. A survey of students' use of and satisfaction with university subscribed online-resources in two specialized universities in a developing country. Library Hi Tech News, 30.3

Ajzen, I.1991. The theory of planned behaviour. Organisational Behaviour and Human Decision processes, 50, 179-211.

Ajzen, I. 2006. Constructing a TPB Questionnaire: Conceptual and Methodological Considerations. Retrieved June 27, 2017 from the World Wide Web: http://www.people.umass.edu/aizen/pdf/tpb.measurement.pdf.

Bandura, A. 1977. Self-efficacy: Toward a unifying theory of behavioural change. Psychological Review, 84, 191-215.

Bandura, A. 1986. Self-efficacy mechanism in human agency. American Psychologist, 37, 122-147.

Dange, J.K.2010. Postgraduate students computing confidence, computer and internet usage at Kuvempu University-An Indian Study. International Journal of Instruction 3(2), Retrieved April, 14th, 2016 from www.e-yi.net.

Dilek-Kayaoglu, H. 2008. Use of electronic journals by faculty at Istanbul University, Turkey: The results of survey. Journal of academic librarianship, 34(3): 239-247. Available: http://eric.ed.gov/?id=EJ794713 [28 February 2017]

Emmanuel,O.S and Jegede,O.R. 2011. Information Needs and Information Seeking Behaviour and Use of Information Resources by MBA Students at a Nigerian University. African Research Review. An International Multidisciplinary Journal, Ethiopia 5,4: 21: 250-264

Hammed, A. and Popoola, S. O. 2006. Selection of sampling and sampling technique. In: Alegbeleye Gabriel O., Mabawonku, Iyabo and Fabunmi, Martins (ed.): Research Methods in Education, Faculty of Education, University Ibadan. $138-154$

Haridasan, S. \& Khan, M. 2009. Impact of E-Resources by Social Scientists in National Science Documentation Centre (NASSDOC), India. The Electronic Library 27: 1

Ibrahim, A.E.and Najjar 2008. Use and user perception of electronic resources in the United Arab Emirates University (UAEU) Library journal vol.54

Ladhari, R. 2009. Service quality, emotional satisfaction, and behavioural intentions: A study in the hotel industry. Managing Service Quality. 19, 3: 308-331

Sam, H.K. Othman, A.E.A and Nording, Z.S. 2011. Computer self-efficacy, computer anxiety and attitude towards the internet: a study among undergraduates in UNIMAS. Journal of educational technology 8, 4

Shuling, W. 2007. "Investigation and analysis of current use of electronic resources in university libraries". Library $\begin{array}{llllll}\text { Management. } & \text { Vol, } & \text { 28, } & \text { no. } & \text { Available } & \text { at: }\end{array}$ 
http://www.emeraldinsight.com/Insight/ViewContentServlet?Filename=Published/EmeraldFullTe xtArticle/Articles/0150280107.html.

Sinh, N. H., and Nhung, H. T. H. 2012. Users' searching behaviour in using online databases at Vietnam National University, Ho Chi Minh City. Library Management, 33,8/9.

Smith, J. G. 2011. The impact of electronic communications on the science communication process - investigating crystallographers in South Africa. IFLA journal. 33, 2.

Swain, D. P. 2010. Students' keenness on use of e-resources. The Electronic Library, 28, 4.

Tabassum, M. Roknuzzaman, M. and Islam, M. M. 2015. Usage of digital library system at a university in Bangladesh, Annals of Library and Information Studies, 62: 94-103

Tan, G., Sim, J., Ooi, K. and Phusavat, K. 2012 'Determinants of mobile learning adoption: an empirical analysis', The Journal of Computer Information Systems, 52, 3: 82-91.

Teo, T., and Milutinovic, V. 2015. Modelling the intention to use technology for teaching mathematics among pre-service teachers in Serbia. Australasian Journal of Educational Technology, 31.4: 363-380

Thanuskodi, S. 2012. Use of E-Resources by Post Graduate Engineering Students with Special Reference to Sona College of Technology, Salem: A Survey. In: DK Swain (ed.) Electronic Age Librarianship. New Delhi: Ane Books PVT Ltd.

Venkatesh, V., M. Morris, G. Davis and F. Davis, 2003. User Acceptance of Information Technology: Toward a Unified View. MIS Quarterly, 27, 3.

Yoo, V., Edwards, T. A. A. P., and James, B. 2012. Counselling students computer competency and complex indicators Skills. Journal of Technology in Counselling, 212.

Zhang, L. Ye, P. and Liu, Q. 2011. A survey of the use of electronic resources at seven universities in Wuhan, China. Program: Electronic library and information Systems. 45, 1: 69-82 